\section{Responses to Double Fold}

The Association of Research Libraries is compiling a list of materials related to Nicholson Baker's book, Double Fold: Libraries and the Assault on Paper. The list includes citations for Baker's book, his July 2000 New Yorker article, reviews, articles, interviews and documents written in response to Baker's attack on library preservation activities. The list of responses also contains comprehensive descriptions of several major research library preservation programs (e.g., National Library of Medicine and Harvard University Library), providing a snapshot of the current state of preservation at those institutions. The URL for this site is http://www.arl.org/preserv/baker.html.

\section{Digital preservation Web site}

OCLC and the Research Libraries Group (RLG) have created a Web site called Digital Preservation Commons, which is devoted to promoting discussion about digital preservation and archiving issues. In March 2000, the two organizations announced a partnership to identify and support best practices for long-term retention of digital objects. They formed two working groups, one to investigate preservation metadata and the other to investigate the preferred attributes of a digital archive. Preservation Metadata for Digital Objects: A Review of the State of the Art is a 50-page white paper produced by the metadata working group that is now available on the Web site as a PDF file.

The URL for Digital Preservation Commons is http://www.oclc.org/digitalpreservation/.

\section{ALA publication}

ALA Editions has published The Preservation Program Blueprint by Barbra Buckner Higginbotham and Judith Wild as the sixth number in its series, Frontiers of Access to Library Materials. This 168-page book advocates decentralization and integration of preservation activities into all library functions. Each of the 12 chapters addresses the role and duties of a different position or functional area. The chapters cover the library director, building manager, collection development and acquisitions, circulation and stack maintenance, bind- ing, repair and reformatting, cataloging and materials processing, access services, interlibrary loan, reference and information services, special collections and archival materials, microforms, sound recordings, video formats and new media, and library systems.

The book is available in paperback for $\$ 37.00$ ( $\$ 33.30$ for ALA members) from the ALA online store (http://alastore.ala.org/). ISBN: 08389-0802-0.

\section{Preservation of sound recordings}

The Council on Library and Information Resources (CLIR) has published Folk Heritage Collections in Crisis, a report about preserving 20th-century sound recordings. It is a synopsis of a December 2000 meeting that brought together folklorists, sound engineers, preservation experts, lawyers, librarians, and archivists to consider the challenges of preserving folk heritage collections. The report contains the three keynote presentations, the formal responses, summaries of the discussions and the 27 recommendations made to ensure access, preservation and rights management for these fragile sound collections.

The report is available as a free PDF file or a $\$ 15$ print copy at http://www.clir.org/pubs/ abstract/pub96abst.html. ISBN 1-887334-82-3.

\section{JAIC online}

Back issues of the Journal of the American Institute for Conservation (JAIC) are available online. The $J A I C$ is published three times per year and contains scholarly articles about scientific research, current issues, and technical procedures in the conservation of many types of cultural materials, including books and paper. This new Web site provides full text and images of all the articles published between 1977 and 1999. The articles may be browsed by title or searched by keyword. There are plans to update the database annually with more recent issues and to add issues from the earlier publication, AIC Bulletin. The URL is http://aic.stanford.edu/jaic/.

Jane Hedberg is preservation program officer at Harvard University, e-mail: jane_hedberg@harvard edu; fax: (617) 496-8344 